\title{
Voluntary Alcohol Consumption Is Controlled via the Neuropeptide Y Y1 Receptor
}

\author{
Todd E. Thiele, ${ }^{1}$ Ming Teng Koh, ${ }^{2}$ and Thierry Pedrazzini ${ }^{3}$ \\ ${ }^{1}$ Department of Psychology, University of North Carolina at Chapel Hill, Chapel Hill, North Carolina 27599-3270, \\ 2Department of Psychology and the Alcohol and Drug Abuse Institute, University of Washington, Seattle, Washington \\ 98195, and ${ }^{3}$ Division of Hypertension, University of Lausanne Medical School, CH-1011 Lausanne, Switzerland
}

We have shown previously that voluntary ethanol consumption and resistance to ethanol-induced sedation are inversely related to neuropeptide $Y$ (NPY) levels in NPY-knock-out $\left(\mathrm{NPY}^{-1-}\right)$ and NPY-overexpressing mice. In the present report, we studied knock-out mice completely lacking the NPY Y1 receptor $\left(\mathrm{Y}^{-1-}\right)$ to further characterize the role of the NPY system in ethanol consumption and neurobiological responses to this drug. Here we report that male $\mathrm{Y} 1^{-1-}$ mice showed increased consumption of solutions containing 3, 6, and $10 \%$ (v/v) ethanol when compared with wild-type $\left(\mathrm{Y} 1^{+/+}\right)$control mice. Female $\mathrm{Y}^{-1-}$ mice showed increased consumption of a $10 \%$ ethanol solution. In contrast, $\mathrm{Y}^{-/-}$mice showed normal

Neuropeptide Y (NPY) is a 36 amino acid neurotransmitter that is widely distributed throughout the nervous system (Dumont et al., 1992; Colmer and Wahlestedt, 1993). NPY has been implicated in the control of food intake (Clark et al., 1984; Levine and Morley, 1984), cerebrocortical excitability (Woldbye et al., 1996, 1997), cardiovascular homeostasis (Pedrazzini et al., 1998), and in the integration of emotional behavior (Heilig et al., 1993; Heilig and Widerlov, 1995). Recent evidence suggests that NPY is also involved with neurobiological responses to ethanol. Rats that were selectively bred for alcohol preference have altered levels of NPY in several brain regions compared with alcoholnonpreferring rats (Ehlers et al., 1998; Hwang et al., 1999), and genetic linkage analysis of alcohol-preferring rats identified a chromosomal region that includes the NPY gene (Carr et al., 1998). Voluntary ethanol consumption and resistance to the intoxicating effects of ethanol have been found to be inversely related to NPY levels in knock-out and transgenic mice (Thiele et al., 1998, 2000a), central infusion of exogenous NPY has been shown to modulate ethanol drinking in rats (Badia-Elder et al., 2001a; Kelley et al., 2001), and recent evidence indicates that the NPY system may modulate ethanol consumption and seizure during withdrawal from ethanol in humans (Kauhanen et al., 2000; Ilveskoski et al., 2001; Okubo and Harada, 2001). However,

\footnotetext{
Received Oct. 15, 2001; revised Nov. 26, 2001; accepted Nov. 27, 2001.

This work was supported by National Institutes of Health Grants AA00258 and AA13573 (T.E.T), by the University of Washington Alcohol and Drug Abuse Institute, and by a generous donation from the Brunstad family to T. E. T. We thank G. I. Miura for help with genotyping mice and D. J. Marsh, R. D. Palmiter, and I. L. Bernstein for helpful discussions.

Correspondence should be addressed to Dr. Todd E. Thiele, Department of Psychology, University of North Carolina, Davie Hall, CB\# 3270, Chapel Hill, NC 27599-3270. E-mail: thiele@unc.edu.

Copyright (C) 2002 Society for Neuroscience $\quad 0270-6474 / 02 / 220001-\bullet \$ 15.00 / 0$
}

consumption of solutions containing either sucrose or quinine. Relative to $\mathrm{Y} 1^{+/+}$mice, male $\mathrm{Y} 1^{-/-}$mice were found to be less sensitive to the sedative effects of 3.5 and $4.0 \mathrm{gm} / \mathrm{kg}$ ethanol as measured by more rapid recovery from ethanol-induced sleep, although plasma ethanol levels did not differ significantly between the genotypes. Finally, male $\mathrm{Y}^{-/-}$mice showed normal ethanol-induced ataxia on the rotarod test after administration of a $2.5 \mathrm{gm} / \mathrm{kg}$ dose. These data suggest that the NPY Y1 receptor regulates voluntary ethanol consumption and some of the intoxicating effects caused by administration of ethanol.

Key words: alcohol consumption; sedation; NPY; receptor; knock-out; ataxia

the NPY receptor(s) that mediate neurobiological responses to ethanol and ethanol consumption have not been clearly identified.

In the mouse, NPY acts through at least five receptor subtypes, namely the Y1, Y2, Y4, Y5, and Y6 receptors, all of which couple to heterotrimeric G-proteins that inhibit production of cAMP (Palmiter et al., 1998). The Y1 receptor has been identified in several brain regions that are involved with neurobiological responses to ethanol, including the hippocampus, the hypothalamus, and the amygdala (Ryabinin et al., 1997; Naveilhan et al., 1998). Therefore, we studied alcohol consumption by $\mathrm{Y}^{-/-}$ mice, which completely lack Y1 receptor expression as a result of targeted gene disruption (Pedrazzini et al., 1998), and by normal $\mathrm{Y} 1^{+/+}$mice. $\mathrm{Y} 1^{-/-}$mice grow and reproduce at normal rates despite slightly diminished daily food intake and a reduced refeeding response to starvation. However, these animals develop late-onset obesity because of low energy expenditure (Pedrazzini et al., 1998). We predicted that $\mathrm{Y}^{-/-}$mice would display ethanol-associated phenotypes similar to $\mathrm{NPY}^{-/-}$mice, and thus consume significantly more ethanol and show resistance to the intoxicating effects of ethanol relative to wild-type mice.

This article is published in The Journal of Neuroscience, Rapid Communications Section, which publishes brief, peerreviewed papers online, not in print. Rapid Communications are posted online approximately one month earlier than they would appear if printed. They are listed in the Table of Contents of the next open issue of JNeurosci. Cite this article as: JNeurosci, 2002, 22:RC208 (1-6). The publication date is the date of posting online at www.jneurosci.org.

http://www.jneurosci.org/cgi/content/full/6073 


\section{MATERIALS AND METHODS}

Animals. Generation of the $\mathrm{Y}^{-/-}$mice has been described previously (Pedrazzini et al., 1998). Starting with mice from the original population (Pedrazzini et al., 1998), Y1 ${ }^{-/-}$mice were backcrossed for seven generations into a C57BL/6J background and were then bred with wild-type C57BL/6J mice to obtain heterozygote $\left(\mathrm{Y}^{+/-}\right)$knock-outs. Nonlittermate heterozygous mice were then bred, and $\mathrm{F}_{2}$ mice from this cross yielded $\mathrm{Y}^{-1-}$ mice and $\mathrm{Y}^{+/+}$mice. Littermate mice and their immediate offspring were used in the present studies. Each study described below used mice that were 8-14 weeks of age, before the onset of obesity. Mice were individually housed in plastic mouse cages with ad libitum access to standard rodent chow (Teklad; Harlan, Madison, WI) and water throughout the experiments. The colony room was maintained at $\sim 22^{\circ} \mathrm{C}$ with a $12 \mathrm{hr}$ light/dark cycle. All procedures used in the present research were in compliance with National Institutes of Health guidelines, and the protocols were approved by the University of Washington Animal Care Committee.

Alcohol intake test. Throughout the experiments, fluid intake, food intake, and body weight measures were assessed every $2 \mathrm{~d}$. $\mathrm{Y}^{-1-}$ mice (male, $n=15$; female, $n=10$ ) and $\mathrm{Y}^{+/+}$mice (male, $n=11$; female, $n=12$ ) were habituated in their home cage to drinking from two bottles containing plain water over $6 \mathrm{~d}$. Mice were then given $24 \mathrm{hr}$ access to two bottles, one containing plain water and the other containing ethanol in water. The concentration of ethanol (v/v) was increased every $8 \mathrm{~d}$; mice received $3 \%, 6 \%$, and finally $10 \%$ ethanol over the course of the experiment. The positions of the bottles were changed every $2 \mathrm{~d}$ to control for position preferences. Average ethanol consumption per day was obtained for each ethanol concentration. To obtain a measure of ethanol consumption that corrected for individual differences in mouse size, grams of ethanol consumed per killigram of body weight per day were calculated for each mouse. As a measure of relative ethanol preference, an ethanol preference ratio was calculated at the $10 \%$ ethanol concentration by dividing total ethanol solution consumed by total fluid (ethanol plus water) consumption. Two-way $2 \times 3$ (genotype $\times$ concentration) and $2 \times$ 4 (genotype $\times$ trial) repeated-measures ANOVAs were used for statistical examination of the data.

Sucrose and quinine consumption test. Approximately 2 weeks after ethanol consumption testing, mice (same as above) were given plain water in one bottle and sucrose or quinine in the other bottle. The compounds were presented in the following order: sucrose solutions $(1.70$ and $4.25 \%$ ) followed by quinine solutions ( $0.03 \mathrm{~mm}$ and $0.10 \mathrm{~mm})$. Mice had $48 \mathrm{hr}$ of access to each solution, and the position of the solution was counterbalanced between animals. Milliliters of solution consumed per killigram of body weight per day were calculated for each mouse. The data collected with each taste solution were analyzed separately with two-way $2 \times 2$ (genotype $\times$ concentration) repeated-measures ANOVAs.

Test for sensitivity to ethanol-induced sedation. Naive male $\mathrm{Y}^{-/-}(n=$ $13)$ and $\mathrm{Y}^{+/+}(n=11)$ mice were removed from their home cage and given an intraperitoneal injection of ethanol $[3.5 \mathrm{gm} / \mathrm{kg} ; 20 \%(\mathrm{w} / \mathrm{v})$ mixed in isotonic saline]. At the onset of ethanol-induced sedation, each mouse was placed on its back into a plastic U-shaped trough. The time (in minutes) that elapsed between the ethanol injection and when the mouse could right itself onto all four paws three times within a $30 \mathrm{sec}$ interval was used as the index of time to regain the righting reflex. Approximately 2 weeks after the first injection, the same mice were again given an intraperitoneal injection of ethanol $[4.0 \mathrm{gm} / \mathrm{kg} ; 20 \%(\mathrm{w} / \mathrm{v})$ mixed in isotonic saline], and the time to regain the righting reflex was assessed. These data were analyzed with two-way $2 \times 2$ (genotype $\times$ concentration) repeated-measures ANOVAs.

Accelerating rotarod test. The rotarod test was used to assess sensitivity to drug-induced motor incoordination (herein referred to as ataxia) with naive mice. The rotarod apparatus (Ugo Basile Biological Research, Varese, Italy) consisted of a $3 \mathrm{~cm}$ diameter horizontal rotating rod divided into five $6 \mathrm{~cm}$ sections by tan acrylic disks. The rod was rotated by a motor that accelerated from 4 to $40 \mathrm{rpm}$ over the course of $5 \mathrm{~min}$. For each trial, the mouse was placed on the stationary rod, which was then rotated until the mouse fell. On days 1-3, mice were given three practice trials separated by $1 \mathrm{~min}$. On days $4-5$, mice were given two practice trials, and then a third trial that was immediately preceded by an intraperitoneal injection of saline to habituate them to the injection procedures. On day 6 , mice were given two practice trails. The third trial served as the critical test and was preceded by an intraperitoneal injection of ethanol $[2.5 \mathrm{gm} / \mathrm{kg} ; 20 \%$ (w/v) mixed in isotonic saline]. Latency to fall (in seconds) on the test trial was recorded as the measure of sensitivity to ethanol-induced ataxia.
Plasma ethanol concentrations. Male $\mathrm{Y} 1^{-/-}(n=12)$ and $\mathrm{Y} 1^{+/+}(n=$ 11) mice were given an intraperitoneal injection of ethanol $[3.5 \mathrm{gm} / \mathrm{kg}$; $20 \%(\mathrm{w} / \mathrm{v})$ mixed in isotonic saline; the same low-dose concentration used during sedation testing] and immediately returned to their home cages. At $1 \mathrm{hr}$ after ethanol injection, one-half of the mice were rapidly anesthetized with $\mathrm{CO}_{2}$ and decapitated for blood collection. The remaining mice were anesthetized and decapitated $3 \mathrm{hr}$ after ethanol injection. Plasma ethanol levels were determined via spectrophotometic methods (Enzymatic Determination of Alcohol Test; Sigma, St. Louis, MO) and calculated as milligrams per deciliter. A two-way $2 \times 2$ (genotype $\times$ time) multifactor ANOVA was used to analyze the data.

\section{RESULTS}

\section{Alcohol, sucrose, and quinine consumption tests}

The male $\mathrm{Y} 1^{-1-}$ mice consumed significantly more of each ethanol solution than $\mathrm{Y}^{+/+}$control mice (Fig. $1 a, b$ ). We expressed consumption of $10 \%$ ethanol relative to total fluid consumption (ethanol preference ratio). Both $\mathrm{Y}^{-1-}$ and $\mathrm{Y} 1^{+/+}$mice preferred ethanol to water (preference ratios of $>0.50$ ), a behavior that is characteristic of $\mathrm{C} 57 \mathrm{BL} / 6$ mice (Belknap et al., 1993). Strikingly, despite this high basal consumption of ethanol by wild-type mice, $\mathrm{Y} 1^{-1-}$ mice still showed increased ethanol consumption (Fig. 1c). There were no significant differences between male $\mathrm{Y} 1^{-/-}$and $\mathrm{Y} 1^{+/+}$ mice, nor were there differences over time, in measures of average body weight $\left(\mathrm{Y} 1^{-/-}\right.$mice, $26.0 \pm 0.3 \mathrm{gm} ; \mathrm{Y} 1^{+/+}$mice, $26.5 \pm 0.6 \mathrm{gm})$, average food intake ( $\mathrm{Y} 1^{-\prime-}$ mice, $154.6 \pm$ $5.2 \mathrm{gm} \cdot \mathrm{kg}^{-1} \cdot \mathrm{d}^{-1} ; \mathrm{Y}^{+/+}$mice, $\left.149.9 \pm 3.8 \mathrm{gm} \cdot \mathrm{kg}^{-1} \cdot \mathrm{d}^{-1}\right)$, or average water consumption ( $\mathrm{Y} 1^{-/-}$mice, $67.0 \pm 5.6$ $\mathrm{ml} \cdot \mathrm{kg}^{-1} \cdot \mathrm{d}^{-1} ; \mathrm{Y}^{+/+}$mice, $\left.84.7 \pm 19.1 \mathrm{ml} \cdot \mathrm{kg}^{-1} \cdot \mathrm{d}^{-1}\right)$ during the alcohol consumption test. To determine whether the $\mathrm{Y} 1^{-1-}$ mice exhibited general differences in taste preference or consumption of solutions containing calories, we tested male mice with sucrose (a caloric compound) and quinine solutions, using the same protocol as above. We used these tastants because previous research has indicated that rodents perceive the taste of alcohol as a sweet-bitter compound (Kiefer et al., 1990). There were no significant differences between the genotypes in consumption of either sucrose or quinine solutions (Fig. 1d). Thus, increased consumption of alcohol by male $\mathrm{Y} 1^{-1-}$ mice does not appear to be associated with altered taste preference or caloric need.

Female $\mathrm{Y} 1^{-/-}$and $\mathrm{Y} 1^{+/+}$mice were also tested for consumption of ethanol solutions. Female $\mathrm{Y} 1^{-1-}$ mice consumed significantly more of the $10 \%$ ethanol solution (Fig. $2 a-c$ ), but unlike male $\mathrm{Y}^{-/-}$mice, they did not show significant altered consumption of the 3 and $6 \%$ ethanol solutions, suggesting a possible interaction between gender and expression of phenotypes associated with the gene mutation. However, similar to the male mice, increased consumption of the $10 \%$ ethanol solution by female $\mathrm{Y} 1^{-1-}$ mice was impressive given the already high level of ethanol consumption by wild-type mice. During ethanol consumption testing, the female $\mathrm{Y} 1^{-/-}$and $\mathrm{Y} 1^{+/+}$mice did not differ in measures of average body weight ( $\mathrm{Y} 1^{-/-}$mice, $22.4 \pm 1.0 \mathrm{gm}$; $\mathrm{Y} 1^{+/+}$mice, $22.7 \pm 0.5 \mathrm{gm}$ ) or average water consumption $\left(\mathrm{Y}^{-/-}\right.$mice, $82.8 \pm 13.6 \mathrm{ml} \cdot \mathrm{kg}^{-1} \cdot \mathrm{d}^{-1} ; \mathrm{Y}^{+/+}$mice, $102.7 \pm$ $12.4 \mathrm{ml} \cdot \mathrm{kg}^{-1} \cdot \mathrm{d}^{-1}$ ). Furthermore, female $\mathrm{Y}^{-/-}$mice did not show altered consumption of solutions containing either sucrose or quinine (Fig. $2 d$ ).

\section{Ethanol-induced sedation test and plasma ethanol levels}

$\mathrm{NPY}^{-/-}$mice showed reduced sensitivity to ethanol-induced sedation (Thiele et al., 1998). Therefore, we sought to determine 


\section{Males}
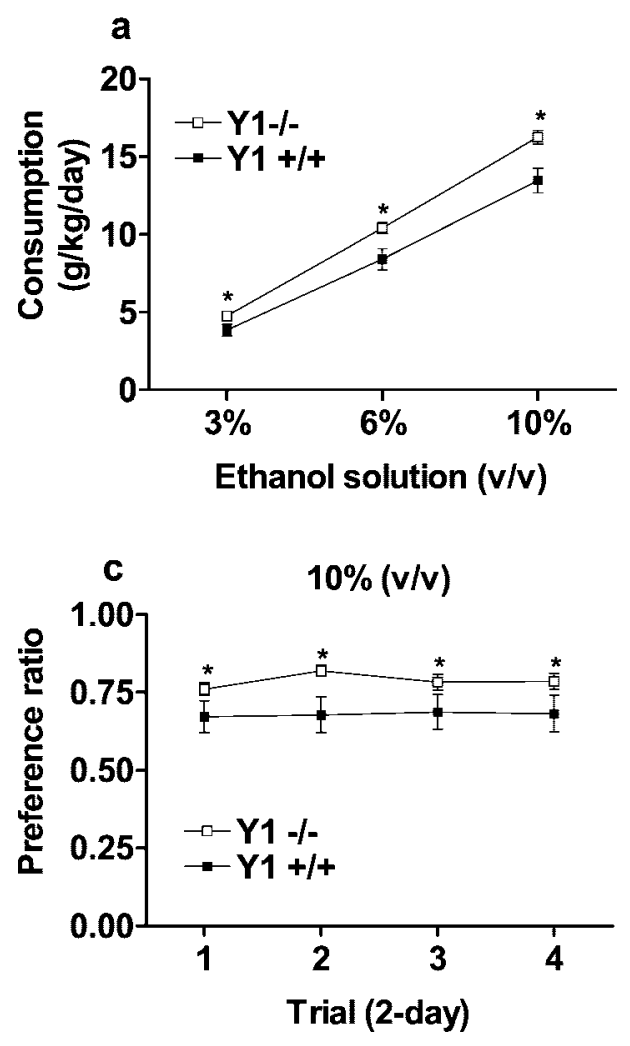
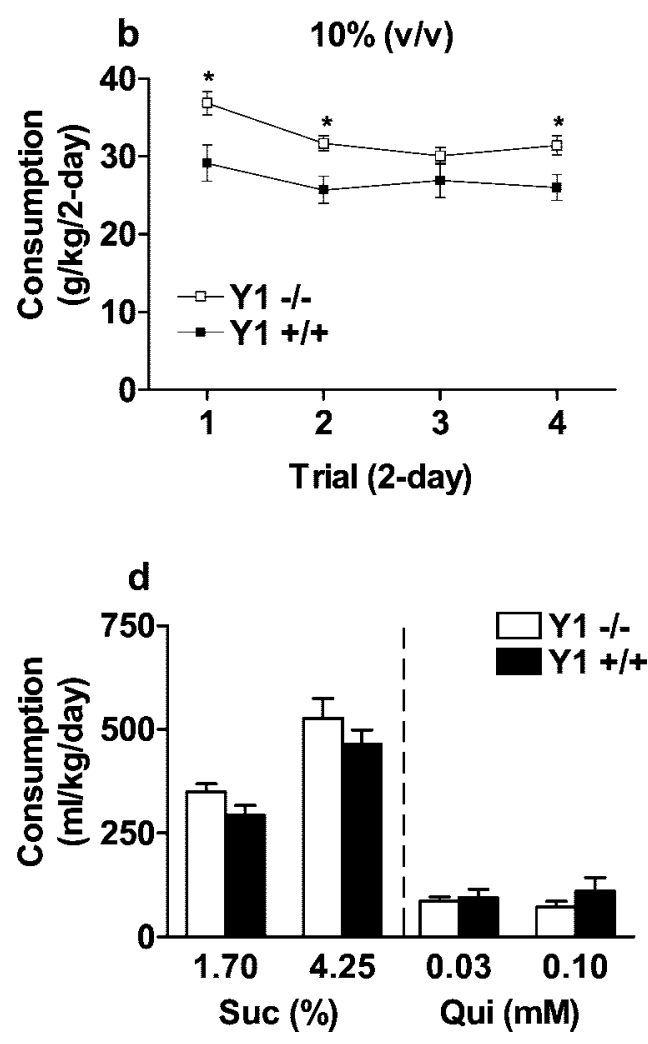

Figure 1. Consumption of solutions containing ethanol or nonalcoholic tastants by male $\mathrm{Y} 1$ receptor knock-out $\left(\mathrm{Y}^{-1-}\right)$ and wild-type $\left(\mathrm{Y}^{+/+}\right)$mice maintained on an inbred C57BL/6 genetic background. $a$, Consumption (grams per killigram per day) of each ethanol solution (8 d average). $b$, Consumption (grams per killigram per $2 \mathrm{~d}$ ) of the $10 \%$ ethanol solution. Consumption measures were collected every 2 d. $c$, Ethanol-preference ratios (volume of ethanol consumed/total volume of fluid consumed) as a measure of relative ethanol preference during consumption of the $10 \%$ ethanol solution. $d$, Consumption (milliliters per killigram per day) of solutions containing sucrose $(S u c)$ or quinine (Qui). Mice had $2 \mathrm{~d}$ of access to each taste solution. All values are means \pm SEM. ANOVAs indicated that male $\mathrm{Y}^{-/-}$ mice drank significantly more ethanol than male $\mathrm{Y} 1{ }^{+1+}$ mice. ${ }^{*} p<0.05$. whether $\mathrm{Y}^{-/-}$mice were resistant to the sedative effects of ethanol. We used male mice because they showed increased consumption of each ethanol solution tested. Male $\mathrm{Y} 1^{-1-}$ mice were resistant to the sedative effects of ethanol, regaining their righting reflex sooner than $\mathrm{Y} 1^{+/+}$mice after injection of both the 3.5 and $4.0 \mathrm{gm} / \mathrm{kg}$ ethanol doses (Fig. $3 a$ ). Furthermore, differences in sensitivity to the sedative effects of ethanol (and ethanol consumption) do not appear to be secondary to differences in acute clearance of ethanol, because plasma ethanol concentrations at 1 and $3 \mathrm{hr}$ after ethanol administration did not differ between the genotypes (Fig. $3 b$ ).

\section{Accelerating rotarod test}

It has been suggested previously that multiple assessment tools should be used when studying knock-out mice to avoid misinterpretation of gene function (Boehm et al., 2000). Therefore, we determined whether male $\mathrm{Y}^{-/-}$mice also showed reduced sensitivity to ethanol-induced motor impairment with the accelerating rotarod test, a common measure of drug-induced ataxia. Relative to wild-type mice, $\mathrm{Y}^{-/-}$mice did not differ in latency to fall from an accelerating rotarod immediately after injection of a $2.5 \mathrm{gm} / \mathrm{kg}$ dose of ethanol (Fig. 3c).

\section{DISCUSSION}

Here we provide evidence suggesting that the NPY Y1 receptor regulates voluntary alcohol consumption and some of the acute intoxicating effects caused by administration of this drug. The high level of alcohol consumption by $\mathrm{Y}^{-/-}$mice does not appear to be related to the taste and/or caloric properties of ethanol, because the $\mathrm{Y} 1^{-/-}$mice showed normal consumption of solutions containing either sucrose or quinine and normal food intake.
Furthermore, resistance to ethanol-induced sedation (and high ethanol consumption) are not likely related to high ethanol metabolism, because the $\mathrm{Y}^{-/-}$mice showed normal plasma ethanol levels. Interestingly, $\mathrm{Y} 1^{-/-}$mice showed normal ethanol-induced ataxia on the rotarod test, suggesting that resistance to the neurobiological effects of ethanol in the $\mathrm{Y} 1^{-/-}$mice may be task-dependent, an observation that has been made with another mutant mouse model (Boehm et al., 2000). Alternatively, it is possible that the $2.5 \mathrm{gm} / \mathrm{kg}$ ethanol dose used for the rotarod test may have been too high, thus producing a ceiling effect that prevented the detection of significant differences between the genotypes.

In the brain, NPY acts through Y1, Y2, and Y5 receptors, all of which couple to heterotrimeric $\mathrm{G}$-proteins that inhibit production of cAMP (Heilig and Widerlov, 1995; Gerald et al., 1996). The Y1 and Y5 receptors have been identified as postsynaptic (Michel, 1991; Naveilhan et al., 1998), whereas the Y2 receptor appears to be a presynaptic autoreceptor that inhibits synaptic release of NPY (Chen et al., 1997). The present results with Y1 ${ }^{-/-}$mice are consistent with those obtained with $\mathrm{NPY}^{-/-}$mice (Thiele et al., 1998) and suggest that the actions of NPY on voluntary ethanol consumption and ethanol-induced sedation are modulated by postsynaptic Y1 receptor signaling. Given the postsynaptic location of the Y5 receptor, one might also predict that Y5 receptor knock-out $\left(\mathrm{Y}^{-1-}\right)$ mice would show increased ethanol consumption. However, we have found previously that $\mathrm{Y}^{-1-}$ mice showed normal consumption of solutions containing ethanol (Thiele et al., 2000a). Together, the data suggest that ethanol consumption is modulated by the Y1 receptor, whereas other NPY receptors may not be involved. 


\section{Females}

Figure 2. Consumption of solutions containing ethanol or nonalcoholic tastants by female $\mathrm{Y}^{-1-}$ and $\mathrm{Y} 1^{+/+}$mice maintained on an inbred C57BL/6 genetic background. $a$, Consumption (grams per killigram per day) of each ethanol solution ( $8 \mathrm{~d}$ average). $b$, Consumption (grams per killigram per $2 \mathrm{~d}$ ) of the $10 \%$ ethanol solution. Consumption measures were collected every $2 \mathrm{~d}$. $c$, Ethanol-preference ratios (volume of ethanol consumed/total volume of fluid consumed) as a measure of relative ethanol preference during consumption of the $10 \%$ ethanol solution. $d$, Consumption (milliliters per killigram per day) of solutions containing sucrose $(S u c)$ or quinine (Qui). Mice had $2 \mathrm{~d}$ of access to each taste solution. All values are means \pm SEM. ANOVAs indicated that female $\mathrm{Y} 1^{-/-}$mice drank significantly more $10 \%$ ethanol solution than female $\mathrm{Y} 1^{+/+}$mice, but there were no significant genotype differences during assessment of the 3 and $6 \%$ ethanol solutions. $* p<0.05$.
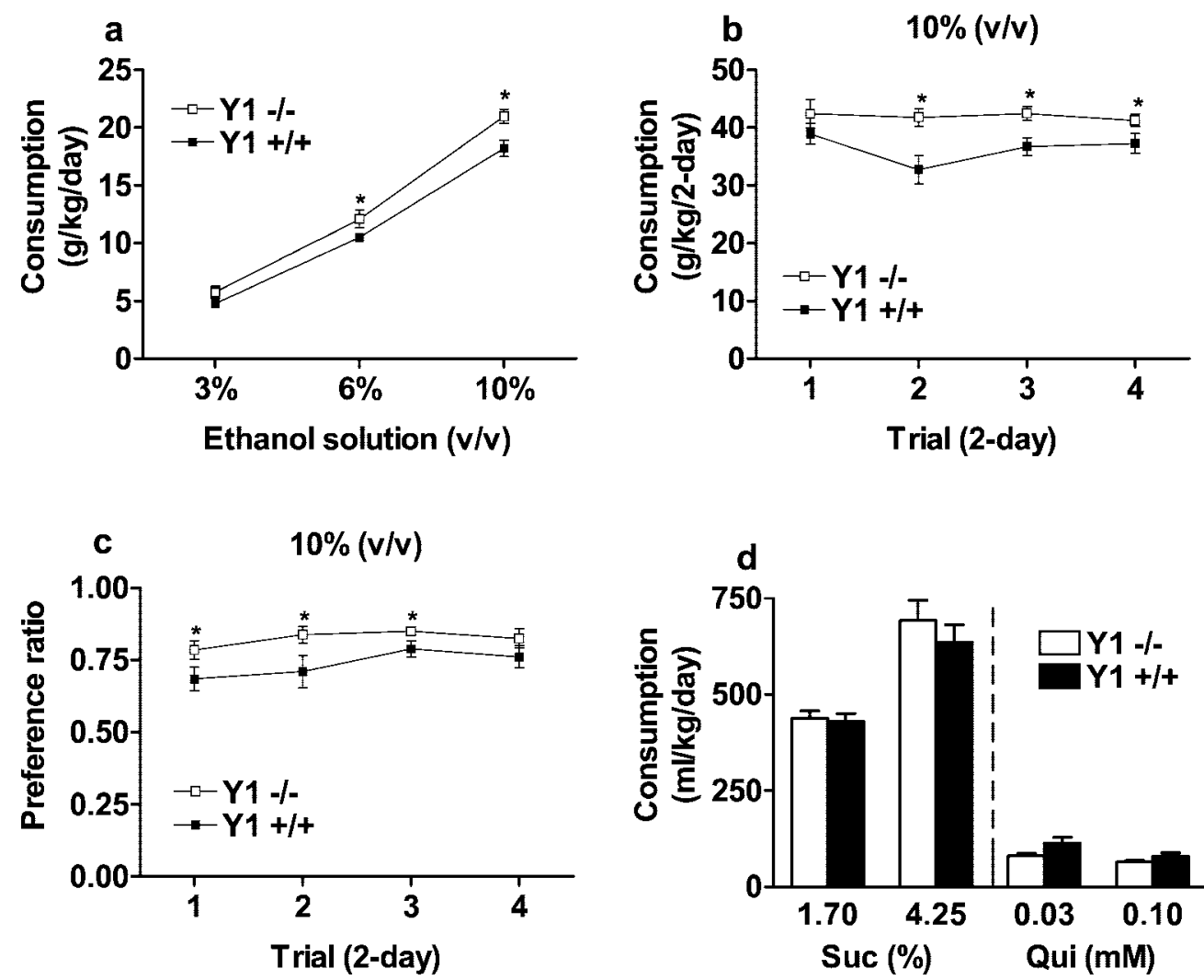

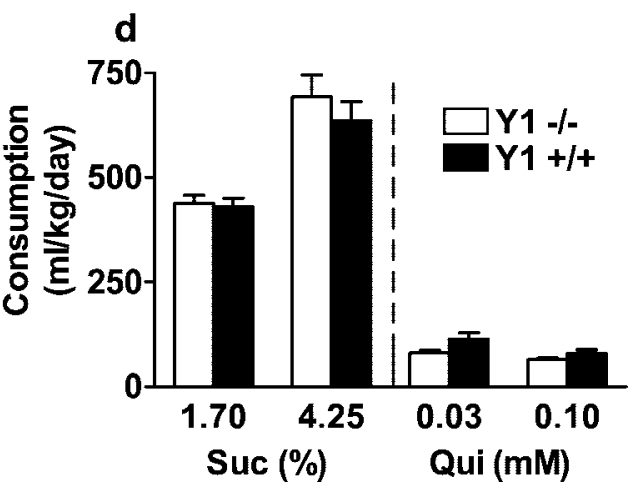

Because ethanol has calories, it is possible that the Y1 receptor modulates alcohol intake via the same hypothalamic system thought to stimulate feeding behavior (Palmiter et al., 1998). However, this does not seem likely, because $\mathrm{Y}^{-/-}$mice drank more ethanol solution yet had normal to reduced daily food intake (Pedrazzini et al., 1998) and did not show altered consumption of the caloric sucrose solution in the present study. Alternatively, there is increasing evidence from both human and animal research indicating that resistance to the intoxicating effects of ethanol is often associated with high levels of ethanol drinking (Schuckit, 1986, 1988, 1994; Thiele et al., 1998, 2000b; Hodge et al., 1999). One possible physiological role for the Y1 receptor may be to promote some of the intoxicating effects of ethanol, perhaps as a mechanism to limit alcohol intake. As such, a lack of Y1 receptor signaling would cause a resistance to the intoxicating effects of ethanol, thus eliminating this protective system and increasing the risk for high alcohol intake. Consistent with this hypothesis is evidence showing that central infusion of NPY potentiated ethanol-induced sleep time in rats (Badia-Elder et al., 2001b) and evidence that Y1 receptor signaling modulates the sedative effects of sodium pentobarbital (Naveilhan et al., 2001).

The Y1 receptor may modulate ethanol consumption by inhibiting cAMP production (Heilig and Widerlov, 1995; Gerald et al., 1996). In fact, recent data provide direct evidence that cAMP and cAMP-dependent protein kinase A (PKA) signaling regulate neurobiological responses to ethanol. Mutant mice lacking the RII $\beta$ subunit of PKA drank more ethanol and were resistant to ethanol-induced sedation despite normal plasma ethanol levels (Thiele et al., 2000b). A similar pattern of results was found in mice with targeted disruption of the stimulatory G-protein Gs $\alpha$, whereas transgenic mice overexpressing Gs $\alpha$ in forebrain showed reduced ethanol sensitivity (Wand et al., 2001). Finally, inactivation of the Drosophila amnesiac gene, which encodes a secreted neuropeptide that stimulates cAMP production, rendered flies more sensitive to ethanol-induced sedation (Moore et al., 1998). It will be important to determine whether $\mathrm{Y} 1^{-1-}$ mice have altered levels of cAMP and/or PKA, and whether cAMP antagonists can "normalize" ethanol drinking in these mice.

Several examples in the literature indicate that ethanol consumption and resistance are inversely related to NPY signaling. Both the $\mathrm{NPY}^{-1-}$ and $\mathrm{Y}^{-/-}$mice showed increased ethanol consumption and reduced sensitivity to ethanol-induced sedation, whereas NPY-overexpressing mice showed low ethanol consumption and increased ethanol-induced sleep time (Thiele et al., 1998). Furthermore, both the Indiana alcohol-preferring and high alcohol drinking rats, which were selectively bred for high ethanol consumption, showed reduced NPY levels in the central nucleus of the amygdala (Ehlers et al., 1998; Hwang et al., 1999), and central infusion of NPY was found to attenuate the high ethanol consumption but increase ethanol-induced sleep time in alcohol preferring rats (Badia-Elder et al., 2001a,b). However, it has also been reported that central inf usion of NPY either has no effect on ethanol drinking (Slawecki et al., 2000) or can increase ethanol consumption when infused directly into the paraventricular nucleus of the hypothalamus (Kelley et al., 2001). The latter example suggests that NPY may have brain region-specific effects on voluntary ethanol consumption.

It is noteworthy that the $\mathrm{Y} 1$ receptor has been shown to mediate the anti-anxiety actions of NPY (Heilig et al., 1993). 

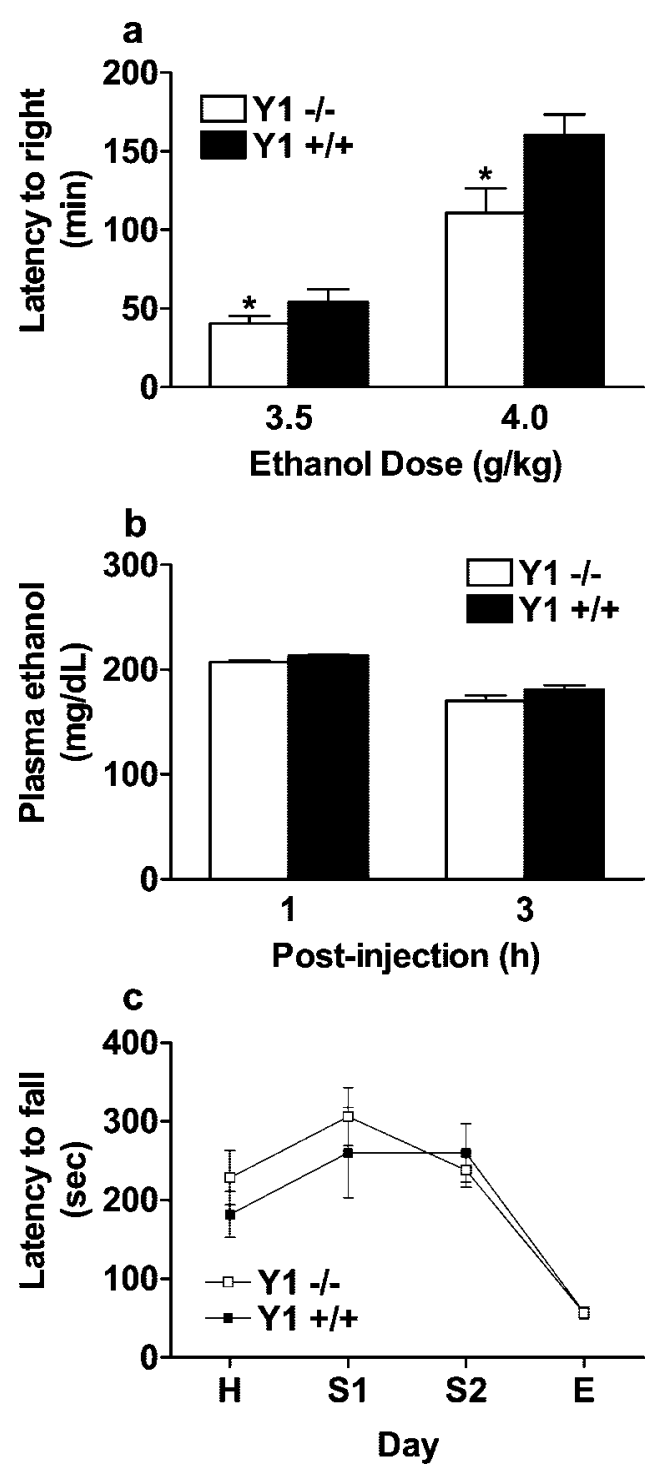

Figure 3. Tests of ethanol-induced intoxication and assessment of plasma ethanol levels with male $\mathrm{Y}^{-/-}$and $\mathrm{Y}^{+/+}$mice. $a$, The time that elapsed between intraperitoneal injection of ethanol $[3.5$ or $4.0 \mathrm{gm} / \mathrm{kg}$; $20 \%(\mathrm{w} / \mathrm{v})$ mixed in isotonic saline] and when the mouse could right itself onto all four paws three times within a $30 \mathrm{sec}$ interval was used as the index of latency to right (in minutes). $b$, Plasma ethanol levels (in milliliters per deciliter) 1 or $3 \mathrm{hr}$ after intraperitoneal injection of ethanol [3.5 gm/ $\mathrm{kg} ; 20 \%(\mathrm{w} / \mathrm{v})$ mixed in isotonic saline]. $c$, Latency to fall (in seconds) from the rotarod on the last trial of each test day. Mice were first habituated $(H)$ to walking on the rotarod apparatus for $3 \mathrm{~d}$. For the next $2 \mathrm{~d}$, mice were given an intraperitoneal injection of saline ( $S 1$ and $S 2$ ) before placement on the rotarod, and on the final day of the study $(E)$, mice were given an intraperitoneal injection of ethanol $[2.5 \mathrm{gm} / \mathrm{kg} ; 20 \%$ $(\mathrm{w} / \mathrm{v})$ mixed in isotonic saline] immediately before rotarod testing. All values are means \pm SEM. ANOVAs indicated that $\mathrm{Y} 1^{-1-}$ mice recovered from ethanol-induced sedation significantly sooner than $\mathrm{Y} 1^{+/+}$mice. $* p<0.05$.

Furthermore, both the $\mathrm{P}$ rats and the NPY ${ }^{-/-}$mice show high basal levels of anxiety-associated behaviors (Stewart et al., 1993; Thiele et al., 1998). Thus, high ethanol consumption may be secondary to high levels of anxiety. It will be important to determine whether $\mathrm{Y} 1^{-/-}$mice show altered basal levels of anxiety, and whether there is a direct link between anxiety and alcohol consumption in these knock-out and selectively bred models.

In summary, we show here that the NPY Y1 receptor is important for regulating ethanol intake and sensitivity to the sedative effects of ethanol. Given the health and social problems related to alcohol dependence, central NPY Y1-mediated pathways that regulate ethanol consumption might represent attractive therapeutic targets for the treatment of alcohol use disorders.

\section{REFERENCES}

Badia-Elder NE, Stewart RB, Powrozek TA, Roy KF, Murphy JM, Li TK (2001a) Effect of neuropeptide Y (NPY) on oral ethanol intake in Wistar, alcohol-preferring (P), and -nonpreferring (NP) rats. Alcohol Clin Exp Res 25:386-390.

Badia-Elder NE, Stewart RB, Roy KF, Kennedy MJ, Murphy JM, Li TK (2001b) Effects of neuropeptide Y (NPY) on ethanol-induced sleep time in alcohol-preferring (P) rats. Alcohol Clin Exp Res 25:15.A.

Belknap JK, Crabbe JC, Young ER (1993) Voluntary consumption of ethanol in 15 inbred mouse strains. Psychopharmacology 112:503-510.

Boehm II SL, Schafer GL, Phillips TJ, Browman KE, Crabbe JC (2000) Sensitivity to ethanol-induced motor incoordination in 5-HT(1B) receptor null mutant mice is task-dependent: implications for behavioral assessment of genetically altered mice. Behav Neurosci 114:401-409.

Carr LG, Foroud T, Bice P, Gobbett T, Ivashina J, Edenberg H, Lumeng L, Li T-K (1998) A quantitative trait locus for alcohol consumption in selectively bred rat lines. Alcohol Clin Exp Res 22:884-887.

Chen X, DiMaggio DA, Han SP, Westfall TC (1997) Autoreceptorinduced inhibition of neuropeptide Y release from PC-12 cells is mediated by Y2 receptors. Am J Physiol 273:H1737-H1744.

Clark JJ, Karla PS, Crowle WR, Karla SP (1984) Neuropeptide Y and human pancreatic polypeptide stimulate feeding behavior in rats. Endocrinology 115:427-429.

Colmer WF, Wahlestedt C (1993) The biology of neuropeptide Y and related peptides. Totowa, NJ: Humana.

Dumont Y, Martel JC, Fournier A, St. Pierre S, Quirion R (1992) Neuropeptide Y and neuropeptide Y receptor subtypes in brain and peripheral tissues. Prog Neurobiol 38:125-167.

Ehlers CL, Li TK, Lumeng L, Hwang BH, Somes C, Jimenez P, Mathe AA (1998) Neuropeptide Y levels in ethanol-naive alcohol-preferring and nonpreferring rats and in Wistar rats after ethanol exposure. Alcohol Clin Exp Res 22:1778-1782.

Gerald C, Walker MW, Criscione L, Gustafson EL, Batzl-Hartmann C, Smith KE, Vaysse P, Durkin MM, Laz TM, Linemeyer DL, Schaffhauser AO, Whitebread S, Hofbauer KG, Taber RI, Branchek TA, Weinshank RL (1996) A receptor subtype involved in neuropeptideY-induced food intake. Nature 382:168-171.

Heilig M, Widerlov E (1995) Neurobiology and clinical aspects of neuropeptide Y. Critical Rev Neurobiol 9:115-136.

Heilig M, McLeod S, Brot M, Heinrichs SC, Mensaghi F, Koob GF, Britton KT (1993) Anxiolytic-like action of neuropeptide Y: mediation by $\mathrm{Y} 1$ receptors in amygdala, and dissociation from food intake effects. Neuropsychopharmacology 8:357-363.

Hodge CW, Mehmert KK, Kelley SP, McMahon T, Haywood A, Olive MF, Wang D, Sanchez-Perez AM, Messing RO (1999) Supersensitivity to allosteric $\operatorname{GABA}(\mathrm{A})$ receptor modulators and alcohol in mice lacking PKC $\epsilon$. Nat Neurosci 2:997-1002.

Hwang BH, Zhang JK, Ehlers CL, Lumeng L, Li TK (1999) Innate differences of neuropeptide Y (NPY) in hypothalamic nuclei and central nucleus of the amygdala between selectively bred rats with high and low alcohol preference. Alcohol Clin Exp Res 23:1023-1030.

Ilveskoski E, Kajander OA, Kehtimaki T, Kannus T, Karhunen PJ, Heinala P, Virkkunen M, Alho H (2001) Association of neuropeptide Y polymorphism with the occurrence of type 1 and type 2 alcoholism. Alcohol Clin Exp Res 25:1420-1422.

Kauhanen J, Karvonen MK, Pesonen U, Koulu M, Tuomainen TP, Uusitupa MI, Salonen JT (2000) Neuropeptide Y polymorphism and alcohol consumption in middle-aged men. Am J Med Genet 93:117-121.

Kelley SP, Nannini MA, Bratt AM, Hodge CW (2001) Neuropeptide-Y in the paraventricular nucleus increases ethanol self-administration. Peptides 22:515-522.

Kiefer SW, Bice PJ, Orr MR, Dopp JM (1990) Similarity of taste reactivity responses to alcohol and sucrose mixtures in rats. Alcohol 7:115-120.

Levine AS, Morley JE (1984) Neuropeptide Y: a potent inducer of consummatory behavior in rats. Peptides 5:1025-1029.

Michel MC (1991) Receptors for neuropeptide Y: multiple subtypes and multiple second messengers. Trends Pharmacol Sci [Erratum (1991) 12:448] 12:389-394.

Moore MS, DeZazzo J, Luk AY, Tully T, Singh CM, Heberlein U (1998) Ethanol intoxication in Drosophila: genetic and pharmacological evidence for regulation by the cAMP signaling pathway. Cell 93:997-1007.

Naveilhan P, Neveu I, Arenas E, Ernfors P (1998) Complementary and 
overlapping expression of Y1, Y2, and Y5 receptors in the developing and adult mouse nervous system. Neuroscience 87:289-302.

Naveilhan P, Canals JM, Valjakka A, Vartiainen J, Arenas E, Ernfors P (2001) Neuropeptide Y alters sedation through a hypothalamic Y1mediated mechanism. Eur J Neurosci 13:2241-2246.

Okubo T, Harada S (2001) Polymorphism of the neuropeptide Y gene: an association study with alcohol withdrawal. Alcohol Clin Exp Res 25:59S-62S.

Palmiter RD, Erickson JC, Hollopeter G, Baraban SC, Schwartz MW (1998) Life without neuropeptide Y. Recent Prog Horm Res 53:163-199.

Pedrazzini T, Seydoux J, Kunstner P, Aubert JF, Grouzmann E, Beermann F, Brunner HR (1998) Cardiovascular response, feeding behavior, and locomotor activity in mice lacking the NPY Y1 receptor. Nat Med 4:722-726.

Ryabinin AE, Criado JR, Henriksen SJ, Bloom FE, Wilson MC (1997) Differential sensitivity of c-Fos expression in hippocampus and other brain regions to moderate and low doses of ethanol. Mol Psychiatry 2:32-43.

Schuckit MA (1986) Biological markers in alcoholism. Prog Neuropsychopharmacol Biol Psychiatry 10:191-199.

Schuckit MA (1988) Reactions to alcohol in sons of alcoholics and controls. Alcohol Clin Exp Res 12:465-470.

Schuckit MA (1994) Low level of response to alcohol as a predictor of future alcoholism. Am J Psychiatry 151:184-189.
Slawecki CJ, Betancourt M, Walpole T, Ehlers CL (2000) Increases in sucrose consumption, but not ethanol consumption, following ICV NPY administration. Pharmacol Biochem Behav 66:591-594.

Stewart RB, Gatto GJ, Lumeng L, Li T-K, Murphy JM (1993) Comparison of alcohol-preferring $(\mathrm{P})$ and nonpreferring $(\mathrm{NP})$ rats on tests of anxiety and for the anxiolytic effects of alcohol. Alcohol 10:1-10.

Thiele TE, Marsh DJ, Ste Marie L, Bernstein IL, Palmiter RD (1998) Ethanol consumption and resistance are inversely related to neuropeptide Y levels. Nature 396:366-369.

Thiele TE, Miura GI, Marsh DJ, Bernstein IL, Palmiter RD (2000a) Neurobiological responses to ethanol in mutant mice lacking neuropeptide Y or the Y5 receptor. Pharmacol Biochem Behav 67:683-691.

Thiele TE, Willis B, Stadler J, Reynolds JG, Bernstein IL, McKnight GS (2000b) High ethanol consumption and low sensitivity to ethanolinduced sedation in protein kinase A-mutant mice. J Neurosci 20:RC75:1-6.

Wand G, Levine M, Zweifel L, Schwindinger W, Abel T (2001) The cAMP-protein kinase A signal transduction pathway modulates ethanol consumption and sedative effects of ethanol. J Neurosci 21:5297-5303.

Woldbye DP, Madsen TM, Larsen PJ, Mikkelsen JD, Bolwig TG (1996) Neuropeptide Y inhibits hippocampal seizures and wet dog shakes. Brain Res 737:162-168.

Woldbye DP, Larsen PJ, Mikkelsen JD, Klemp K, Madsen TM, Bolwig TG (1997) Powerful inhibition of kainic acid seizures by neuropeptide Y via Y5-like receptors. Nat Med 3:761-764. 